\title{
Religious ethics, Christianity, and war
}

\section{Henrik Syse}

This article discusses elements within Christian ethics and anthropology that have ramifications for the ethics and laws of war. The author argues that several distinctively Christian conceptions of morality and of human beings contribute importantly to the idea of just war, namely the Christian (and more specifically Augustinian) view of history, the Christian view of killing, and the Christian view of sin and grace. While other religious and philosophical traditions also offer significant contributions to a normative discussion about armed force, it remains a fact that Christian thought, historically speaking, has furnished much of the groundwork of what we today know as the ethics and laws of war, and that the experience of being a Christian in the world has important ramifications for thinking about war and the use of armed force.

Keywords: Christianity, just war, grace, killing, philosophy of history, religious ethics, sin

When examining the historical development of the just war idea, it is easy to come to the conclusion that it has religious, and more specifically Christian, origins. After all, the tradition was developed primarily by Christian theologians and philosophers within the framework of Biblical ethics, and it is often referred back to Saint Augustine, who stands as the most influential originator of Christian political theology.

The close ties between Christianity and just war can be explained further by the special exigencies of a religion that puts its faith not in political institutions but in the love of God and salvation beyond this world, while taking on the momentous political task of being at the helm of an Empire. Christianity, disinterested at most in the details of political rule and this-worldly conflict if we are to judge from the New Testament, was at an early stage thrust into the role of being protector of political communities in both the Greek and Latin worlds. This forced its leading theologians, 
jurists, and philosophers to face the quandaries of military power: whether to use it, and if so, how. Spanning twelve decades from Augustine in the early 5th century to Francisco Suarez and Hugo Grotius in the early 17th century, a richly nuanced line of thought developed, which provided a morally informed grounding for the use of military force. ${ }^{1}$ There can seemingly be little controversy in calling this tradition Christian. However, for several reasons, the seemingly obvious link between Christianity and just war ideas can also be challenged.

First, and historically speaking, the roots of just war must be placed earlier than Augustine. For instance, the Athenian historian Thucydides, by starkly portraying the conflict between amoral realism and appeals to morality, made an important contribution to normative reflection on war. Plato wrote dialogues dealing with a number of military questions, challenging widespread Greek assumptions about war from a moral standpoint. Also, Cicero developed an ethics of warfare that prefigures many, if not most, tenets of later just war tradition. It is therefore not true to say that just war is a Christian invention. ${ }^{2}$

Second, other religions have also debated justice and warfare. Hence, asserting a close link between Christianity and just war is biased and unjustified. Recent studies of sources in non-Christian religions betray a host of partly parallel and partly original perspectives on the moral aspects of waging war. ${ }^{3}$

Third, while Christian authors have contributed to the development of ideas on just war and subsequently also international law, Christian political actors have also represented standpoints and actions which are very much at odds with an ethical approach to war. Two seemingly obvious cases are the Medieval Crusades and the actions and policies of the Conquistadors in South America. Hence, linking ideas about restraint and morality in war to Christianity risks obscuring the variety of views within - and the significant brutality and bellicosity of - Christian tradition(s).

Finally, if an ethics of war is to be made effective and convincing in a modern globalized, pluralistic, and (at least in some parts of our globe) secularized world, we must do our best to devise a set of ethical standards that are not dependent on any specifically Christian or religious basis. Thus, the portrayal of just war as a Christian tradition does little to secure its broad recognition or present-day relevance.

Although I think it is vital, even for the limited purposes of this article, to have these arguments noted, I will not debate them all here. Suffice it to say that none of them - even if they are all true - actually diminishes the historical role that Christian ethics has played in forming the just war tradition. It is a historical fact that theological reflection furnished the basis of the most influential contributions to what we know today as the ethics and laws of war. Furthermore, and this is the crux of my argument, the experi- 
ence of being a Christian in the world has important ramifications for thinking about war and the use of armed force.

My reflections in the following will be divided into three parts: (a) the Christian view of history; (b) the Christian attitude to killing; and (c) the Christian view of sin, forgiveness, and mercy. All three are discussed with the aim of showing how Christian ethics substantively contributes to an ethics of war.

\section{History and utopia}

Christian history is, in one sense, a history of progress. As opposed to a circular view of history, the Bible provides us with a God who interferes in and forms a linear history. The world is not the same now as it once was; certain events have irrevocably changed the world.

This linear view of history has shaped Christian societies in ways both direct and indirect. The modern idea of technological and civilizational progress is arguably rooted in this conception of historical development. However, as historians and philosophers such as Karl Löwith, Eric Voegelin, and Ernest Fortin have shown, the Christian view of history is highly ambivalent, and this ambivalence can be traced back at least to St. Augustine. ${ }^{4}$ For Augustine, this-worldly history between the advent of Christ and the final judgment is marked by a sense of waiting. In this world, empires will come and go and civilizations will rise and fall, yet no great significance should be attached to these events, spiritually speaking. Divine history and secular history are not identical, and secular history is not meaningful in and of itself, but is merely the stage on which the manifold dramas of human life are set. The ambivalence thus consists in a view of God as shaping human history, yet displaying his great plan not on the level of political events, but in a divine line of history centered around the revelation of God's will, especially through Jesus Christ.

While many times challenged by later Christian thinkers, particularly by millenarians and other theological radicals advocating moral purity for the elect and great dissatisfaction with the world as it is, the Augustinian view of history has remained at the heart of most Christian approaches to politics. This does not mean that faith has not been used (many would say exploited) politically, nor that churches have not let themselves be employed in the service of secular rulers. The point is that the mainstream theological view of history has subordinated the material and political vagaries of the here and now to the spiritual reality of the eternal God who exists outside time, and to the moral demands of loving one's neighbor and serving God though example rather than force. This means that the importance of political matters somehow comes to be relativized. And, more 
importantly, there is no path to salvation through material gains or military victories as such.

What we today normally call the Holy War idea - as expressed, for instance, during the Crusades - is seemingly an example of an opposite trend. However, it is arguably at odds with the mainstream Augustinian thrust of the just war idea. ${ }^{5}$ The point to be emphasized is thus the following: given the fact that the just war doctrine mainly has developed on a broadly Augustinian basis (a reasonable historical claim given the centrality of Augustinian thought to Canon Law, to Aquinas and his followers, and to the Protestant Reformation), a view of secular history as being of minor importance to salvation and Christian purity has clearly been a factor in forming the Christian ethics of war. Furthermore, this is a view that implies, morally speaking, that a just war must be restrained by moral considerations. If war in its ordinary, human manifestation were truly holy, divinely ordered as a means to salvation and religious victory, it would itself be the moral yardstick against which other concerns would have to be measured. However, being only a means - and a dangerous one at that, given the temptations to dominate others, display brutality, and seek worldly power in war - it must be guided by the virtues and restraints proper to a Christian life. War cannot provide us with our greatest victories, but it can certainly deal us severe moral defeats.

Thus, the Christian and more specifically Augustinian view of history can be seen as an important constituent of the just war view as we know it today. Indeed, the tradition is marked by what we may call a fundamentally non-sentimental view of war. While war may not be bad in itself, and sometimes may even bring glory to those who fight in it, it always needs a just cause, a reasonable hope of success, and should be avoided if better means to the given ends exist. Hence, war is at its heart a secular enterprise, taking place and correcting wrongs within a history that as such has no direct significance for salvation or eternal life.

This understanding of the Christian philosophy of history can, as already indicated, be challenged by pointing to the Christian tradition of fighting wars (more or less directly) for the faith, most notably the Crusades of the High Middle Ages. My assertion is that the Crusades and other periods of bellicose religious fervor (such as the Conquistadors in South America and the post-Reformation era of religious civil wars) are not fully representative of the Christian just war tradition. I hold to this claim since the view that both the intention and means of warfare must be judged against the aims of warfare, and that the aims of warfare are primarily political and not religious has been the dominant one in just war theory. Further, this view comes directly from a philosophy of history which relativizes the significance of worldly politics for the deeper meaning of human life. In this 
sense, the Christian stamp on the just war tradition is significant and distinctive, in making war a secular means and not a religious end.

\section{Taking human life}

There are two basic attitudes towards the taking of human life that accompany and influence the Christian view of war.

First, taking the life of another human being is prima facie wrong, as witnessed by the fifth commandment of the Decalogue, and by several stories in the Hebrew Scriptures, including not least the story of Cain and Abel. As any reader of the Old Testament knows, however, this did not prevent the Israelite community from taking part in wars that they saw as initiated and condoned by Yahweh. ${ }^{6}$ Hence, we see a difference between the killing of another human being by a private person, and killing as part of a communal enterprise under a legitimate authority. This dualism was carried over into the Christian communities, which helps to explain why they came across as predominantly pacifist in the first centuries AD: it was simply because the rightful wielding of secular power was of no great concern for Christians; it was literally none (or at least not much) of their business. ${ }^{7}$

The fact that warfare soon came to be condoned by mainstream Christianity as a natural part of the tools of politics should, however, not obscure the basic skepticism associated with the taking of human life. Human beings hold a special place in the hierarchy of created substances, having been created in the image and likeness of God, and hence having what we today would call a value or dignity in themselves. Within the Christian sphere of ideas, this is the primary origin of the modern idea of inherent human rights (formulated by 17th century thinkers as «natural rights»): by virtue of being God's creation, human beings are endowed with a certain special dignity, on the basis of which they may claim protection and rights. John Locke was among the foremost thinkers to construe this as a Christian argument with direct ramifications for behavior in violent conflict, especially with regard to behavior towards innocent people who have had little say in the occurrence of aggression, yet are often attacked and brutally mistreated during war. ${ }^{8}$

Second, the taking of human life affects the perpetrator. In Augustine's view, the most basic problem associated with warfare lies in its potential for debasing the actor. As Augustine puts it in his Contra Faustum:

What is it about war that is to be blamed? Is it that those who will die someday are killed so that those who will conquer might dominate in peace? This is the complaint of the timid, not of the religious. The desire for harming, the cruelty of revenge, the restless and implacable mind, the savageness of revolting, the lust for dominating, 
and similar things - these are what are justly blamed in wars (Against Faustus the Manichean, bk. XXII, Ch. 74, trans. Tkacz and Kries; in Reichberg et al. 2006:71).

The same attitude is echoed in practices of penance found among several Christians in the early part of the Middle Ages. Even killing committed under rightful authority for a just cause led to requirements of penance and accompanying rituals. ${ }^{9}$ The law against clerics taking part in fighting, more widespread and long-lasting than the penance rituals, reflected the same perspective, which we today would associate primarily with a virtue-ethical approach: killing is problematic and in some sense impure, and must therefore be restrained and regulated. This does not mean that soldiers fighting in a just war ipso facto were seen as having done anything immoral or otherwise wrong, but they were seen as having taken part in a human activity that poses special risks to its perpetrator, most notably that of acting with a wrong intention.

It would be an exaggeration to view this as a consciously held attitude among most soldiers and armies fighting within Christianity. However, it constitutes an attitude that is nonetheless recognizably Christian: that the perpetrator of violent acts has a special accountability, and that the character of one's actions forms one's own soul as well as the community of which one is a part. This attitude goes back to the very beginning of Christian communities, as is evident in the epistles of the New Testament: a Christian should ideally be seen as different; namely, meek, willing to forgive, not quarrelsome, and loving and friendly, even to those outside one's own community. From such a starting point it is easy to infer that a Christian community and its members will likely suffer moral harm if they readily take part in activities that by their very nature include brutality, violence, and killing.

Hence, we can view the moral aspects of killing from both an «other-oriented» and a «self-oriented» perspective: the other is a creature of God, and hence is due a certain respect and care; and the self is the seat of virtues and vices, the latter of which are easily brought forth through acts of brutality, affecting not only each individual but possibly even the whole community of Christians.

We may infer from this that Christianity has infused the idea of just war with a cautious attitude towards killing as such. This is not the same as a "presumption against war», by which I mean a contingent pacifism that views war as always an evil, but sometimes the only option and thus the lesser evil. ${ }^{10}$ Even though this latter view of the Christian tradition of just war has become popular in recent decades, it is at odds with the predominant face of the just war tradition, at least since Thomas Aquinas. As James Turner Johnson has pointed out, the tradition is marked rather by a presumption against injustice than a basic presumption against war per se. ${ }^{11}$ Nonet- 
heless, the fact that war involves the taking of human life makes it an event that should never be trivialized and always needs justification. The Christian attitude to the sanctity of life also implies that the preservation of life when possible should trump the taking of human life, and that ordering others to take lives is problematic and not to be undertaken lightly, since we are essentially asking people to become the perpetrators of acts which inevitably impact any actor who commits them.

\section{Sin, forgiveness, and grace}

It could be argued that war constitutes the ultimate opposite of the Christian attitude to sinfulness. Christ seemingly urged human beings to turn the other cheek, forgive the perpetrators of wrongs, and rather suffer violence than be the wielders of deadly force. As pointed out above, the difference between the personal and political sphere and the necessity for a community to defend itself help explain why mainstream Christianity nonetheless came to condone war.

Yet, here we are faced with another distinctly Christian element of the just war tradition; namely, that the enemy is not the absolute enemy, since every perpetrator of wrong can come to be touched by the grace and forgiveness of God. Once again, traits within Christian warfare have in practice pointed in a very different direction: the vilification of the enemy (cf. the view of the Saracen or the Turk as the totally «other», and therefore to be treated differently and less humanely). However, the distinction between (in Latin) nocentes and innocentes, between the guilty and the non-guilty, is never absolute within Christian ethics, ${ }^{12}$ for two reasons:

The first reason is the one already alluded to: the grace of God is in principle open to all human beings, and a current sinner or apostate can become a future faithful convert. Hence, total vilification is foreign to the basic thrust of Christian ethics and indeed Christian anthropology.

The second reason brings us back to the Augustinian tradition; namely, to the insistence that all human beings are sinners, and hence all are potentially perpetrators of evil. This anthropological fact somehow evens out the moral difference between good and evil human beings, and thus creates another obstacle to thinking in terms of the absolute enemy and total evil. While it is often said that a sacralization of war is the ultimate harbinger of good-evil distinctions, creating the grounding for ideological warfare with no moral limitations, ${ }^{13}$ it can be said with equal justification that the very heart of Christian moral theology opposes absolute demarcations between good and evil human beings.

Admittedly, there is an important strand of the just war tradition which subsumes just punishment under the heading of just cause for using armed 
force, hence viewing war as a retribution for $\sin .{ }^{14}$ Also, there is no doubt that Christianity views evil as actually present in the world, which explains the need for war in the first place. Still, the opposition to using warfare for the sake of pure vengeance or, even more dramatically, in order to obtain the total obliteration of an enemy, is persistent within the tradition. This arguably comes from the Christian view of good and evil as co-present within and among human beings, and the accompanying emphasis on forgiveness of wrongs as the ultimate expression of God's grace in this world.

\section{Conclusions}

I have tried to show above that three basic constituents of Christian theology have important implications for one's view of warfare. It is not farfetched to argue that all of these have come out in the just war tradition as it has developed over the past two millennia, and as it is known today. However, my thesis is not one of exclusivity, nor one of incontrovertible evidence for historical influence. In other words, these same traits and attitudes may have had other origins. Hence, in the modern just war tradition, emphases on limited warfare and resistance to absolute distinctions between the noble defender and the total enemy may have - and indeed do have - origins also elsewhere, especially in the Enlightenment ideals of reason, toleration, and pluralism (which themselves, however, were formed within and colored by Christian and Gospel values).

The basic fact remains that the just war tradition traces many of its perspectives back to Christian theology. Indeed, all the essential criteria and distinctions that we associate with the tradition today - and which have had such influence on international law and even on modern international politics - hark back to authors consciously writing within a Christian framework, building on Christian theology; among the most important of these authors are Augustine, Thomas Aquinas, Francisco de Vitoria, Francisco Suarez, Hugo Grotius, and Samuel Pufendorf.

Hence, we may safely say that moral attitudes within the just war tradition are likely to mirror key concerns within Christian moral theology, and it is three such concerns I have delineated above. Some may prefer to be even more careful - and realist-oriented - in drawing such conclusions, and express the view that the emergence of restraints in war has little to do historically with Christian views of history, killing, or grace, and much more to do with politics and self-interest. Yet even then it may be held that the above-mentioned elements of Christian theology can usefully buttress the just war view, by which I mean the view that warfare should be limited, should be used only to respond to certain kinds of causes, and should always seek lasting peace between enemies. In other words, Christian ethics 
seems to provide us with a suitable, developed, and well-considered framework for understanding why justice in war and the quest for peace are so important.

Limited and justified warfare is thus not an enemy of Christian ethics, but is rather a natural outgrowth of deeply held tenets of Christian theology.

We are not thereby concluding that the just war tradition is a Christian tradition, in the sense of growing out of specifically Christian religious concerns. A debate about the trinity or the resurrection of Christ would be explicitly Christian debates in the full sense. War, on the other hand, is one of those events in the world that Christian thinkers and political leaders have had to react to. In doing that, they do act as Christians, but they confront questions of a general human, not specifically Christian sort. Thus, we are dealing here not with a quandary unique to Christianity, but one which Christianity - along with other religions - has had to face and attempt to solve. It is that attempt which has had such influence on our way of conceiving of right and wrong in war today.

\section{Acknowledgments}

Thanks are due to Gregory Reichberg of PRIO and Glenn Hughes of St. Mary's University, San Antonio, for helpful suggestions and advice.

\section{Notes}

1 See Johnson 1975 and 1981 for sound historical overviews of the just war tradition. See Reichberg et al. 2006 for a collection of the main texts of the tradition.

2 See Reichberg et al. 2006: 3-59.

3 See, for instance, Brekke 2006 and Popovsky et al. 2009.

4 See Löwith 1949, e.g., pp. 1-19, 160-173, 191-203; Voegelin 1952, e.g., pp. 107-132; Fortin 1994; Syse 2000.

5 Jonathan Riley-Smith (2002, especially pp. 42-44) compares Augustinian and crusading attitudes to charity and violence. While finding differences between the two, he also points to several continuities and similarities, and reminds us that the self-understanding of the crusader was rarely that of a brutal warrior but of a soldier out to help in a selfless way Christian victims of aggression.

6 See Voegelin 1956, e.g., pp. 208, 264, 451-452, for interesting perspectives on Old Testament warfare.

7 See Johnson 1987: 3-66; Reichberg et al. 2006: 60-69; Swift 1983.

8 See Reichberg et al. 2006: 462-468. See also Moseley 2005.

9 See Verkamp 1988.

10 This view of just war can be found in Miller 1991 and 2002; and among the US Catholic Bishops in their 1983 and 1993 encyclical letters on war, see Reichberg et al. 2006: 669-682. For important rebuttals, see Johnson 1996 and Reichberg 2007. 
11 Johnson 1996.

12 This comes out clearly in Francisco de Vitoria's arguments against the Spanish wars against the Indians of South America; see Reichberg 2003.

13 Hans Morgenthau can be said to take such a view as the basis of his political realism. 14 See, for instance, Brown 2008: 76-77.

\section{Literature}

Brekke, T. (2006) The ethics of war in Asian civilizations. London: Routledge.

Brown, D. (2008) The sword, the cross, and the eagle. Lanham: Rowman \& Littlefield.

Fortin, E. (1994) Introduction. In Augustine: Political writings, eds. E. Fortin \& D. Kries, pp. vii-xxix. Indianapolis: Hackett.

Johnson, J.T. (1975) Ideology, reason, and the limitation of war. Princeton: Princeton University Press.

Johnson, J.T. (1981) Just war tradition and the restraint of war. Princeton: Princeton University Press.

Johnson, J.T. (1987) The quest for peace. Princeton: Princeton University Press.

Johnson, J.T. (1996) The broken tradition. National Interest, 45, pp. 27-36.

Löwith, K. (1949) Meaning in history. Chicago: University of Chicago Press.

Miller, R. (1991) Interpretations of conflict. Chicago: University of Chicago Press.

Miller, R. (2002) Aquinas and the presumption against killing in war. Journal of Religion, 82 (2), pp. 173-204.

Moseley, A. (2005) John Locke's morality of war. Journal of Military Ethics, 4 (2), pp. 119-128.

Popovsky, V., Reichberg, G. \& Turner, N. (eds.) (2009) World religions and norms of war. Tokyo: United Nations University Press.

Reichberg, G. (2003) Philosophy meets war. In The classics of Western philosophy. A reader's guide, eds. J. Gracia, G. Reichberg \& B. Schumacher, pp. 197-203. Oxford: Blackwell.

Reichberg, G. (2007) Is there a "presumption against war» in Aquinas's ethics? In Ethics, nationalism, and just war, eds. G. Reichberg \& H. Syse, pp. 72-98. Washington, DC: Catholic University of America Press.

Reichberg, G., Syse, H. \& Begby, E. (eds.) (2006) Ethics of war. Classic and contemporary readings. Oxford: Blackwell.

Riley-Smith, J. (2002) Crusading as an act of love. In The crusades, ed. T. Madden, pp. 32-50. Oxford: Blackwell.

Swift, L. J. (ed. \& trans.) (1983) The early fathers on war and military service. Wilmington: Michael Glazier.

Syse, H. (2000) Augustinian history and the road to peace: Perspectives from two latter-day Augustinians. Augustinian Studies, 31 (2), pp. 225-239.

Verkamp, B.J. (1988) The moral status of returning warriors in the Early Middle Ages. Journal of Religious Ethics, 16 (2), pp. 223-249.

Voegelin, E. (1952) New science of politics. Chicago: University of Chicago Press.

Voegelin, E. (1956) Israel and revelation. Baton Rouge: Louisiana State University Press. 